\title{
Water Needs Strategy of Major Plant Crops Cultivated in The Countries of Nile River Basin
}

\author{
I.H. Elsokkary; ${ }^{1}$ and A. F. Abukila ${ }^{2}$
}

\begin{abstract}
The Nile River basin is flowing from south to north over 35 degree of latitude and is extending from the humid region to the desert region. The territories of Burundi, DR Congo, Egypt, Eretria, Ethiopia, Kenya, Rwanda, South Soudan, Sudan, Tanzania, and Uganda are located within the Nile River basin. These countries have wide range of rainfall varying from mean values of $1000 \mathrm{~mm} / \mathrm{year}$ in the countries of humid region to less than $20 \mathrm{~mm} / \mathrm{year}$ in countries of semi- desert and desert regions. The mean volumes of water withdrawal, as percentage of renewable water are 5.0 for Burundi, 0.0 for DR Congo, 92.0 for Egypt, 5.0 for Eritrea, 2.0 for Ethiopia, 3.0 for Kenya, 1.0 for Rwanda, 56.0 for Sudan and 1.0 for Uganda.
\end{abstract}

The crop water needs can be supplied from rainfall or from irrigation or by a combination of both. The irrigation water need (IWN) can be obtained by the difference between crop evapotranspiration $\left(\mathbf{E T}_{\text {crop}}\right)$ and the effective rainfall $\left(\mathbf{P}_{\mathrm{e}}\right)$. Accordingly, in this investigation, the" Blanery and Criddle" method for the determination of reference evapotranspiration $\left(\mathrm{ET}_{\mathbf{0}}\right)$ and crop factor $(\mathrm{Kc})$ is employed for the determination of IWN of sorghum (Sorghum bicolor) plant cultivated in the countries of Nile basin. The data obtained indicated, comparatively, that the highest IWN is required by sorghum cultivated in Egypt and Sudan (582 and $524 \mathrm{~mm} / \mathrm{TGP})$ and the lowest is required by DR Congo, Ethiopia, Uganda and south Sudan $(230,239,240$ and $180 \mathrm{~mm} / \mathrm{TGP}$, respectively). As a result of suitable renewable management in irrigation, the expected percentages of water which can be saved from Nile water are 41.9, 48.9, 47.8 and 62.5 for Burundi, DR Congo, Uganda, and S. Sudan, respectively, and can be therefore a supplementary water source for other countries like Egypt and Sudan.

Key Words: Nile River Basin, Irrigation Water Need, Effective rainfall

\section{INTRODUCTION}

Africa is considered one of the driest continents of the world, as well as Australia, with an exception of the Congo/Zaire river basin. As a result of the variations in geology, geomorphology and climate; the continent exhibits major geographical distribution differences in rainfall and natural surface freshwater. As a result, there

\footnotetext{
${ }^{1}$ Department of Soil and Water Sciences, Faculty of Agricultural,

El-Shatby, Alexandria University.Alexandria, Egypt,

E-mail address: elsokkary35@gmail.com

${ }^{2}$ National Water Research Center, Drainage Research institute, Egypt

El-Qanater El-Khairiya post code:13621,

E-mail address: Alaafg@gmail.com

Received October10, 2013, Accepted November17, 2013
}

are spatial and maldistribution of renewable water resources in the continent. Thus, droughts are frequent in most African countries, and each year more people are at risk due to drought and relatively poor development of water resources (Crisman, et al., 2003).

The continent has several major river basins which are characterized by irregular and reliable flow among the areas of these basins (Table 1). Of a great concern, and/among the world's continents; Africa has the largest percentage $(62 \%)$ of its land in international river basin. Thus, problems arise from that most countries can get its water from either within its own borders, from outside its borders or from both (Hutchinson et al., 1995, and FAO, 1997). This makes that the management of most African river basins is not the responsibility of one country but it must be within and under cooperation and fair agreement among countries of the specific river basin (McNeeley, 1999, and Rosegrant et al., 2002).

\subsection{Water scarcity}

The heaviest rainfall, in Africa, occurs near the equator and may exceed $2000 \mathrm{~mm} /$ year and then it diminishes toward the north regions of the continent. Large areas, therefore, are suffering acute water shortage which mostly lies in the northern parts of the continent. It has been assumed that countries with less than 1700 $\mathrm{m}^{3}$ freshwater per person per year are suffering periodic water shortage and countries with below $1000 \mathrm{~m}^{3}$ per person per year will suffer chronic water scarcity (Rosegrant et al., 2002). According to UN projections, by 2025 , a fairly sizable proportion of the population of some African countries will not have sufficient water to meet their basic needs (Alcamo et al., 2000).

Taking into account the "criticality ratio" or the ratio of water withdrawl to the renewable water, which is an indicator of water scarcity, it can be estimated that some African countries are subjected to "high water stress". According to Alcamo et al., (2000), the higher "criticality ratio" the more intensive the use of water of river basin and, occasionally, these high ratios are recorded by downstream users and, therefore, water usage at this condition can be impaired. It is also clear 
that during low flow periods, the chance of absolute water shortages increases. This indicates that criticality ratios equal to or greater than 0.4 are considered "high water stress" and that equal or greater than 0.8 are considered "very high water stress" (Alcamo et al., 2000). According to these ratios, Egypt is considered a country of "very high water stress".

\subsection{The water of Nile Basin}

The Nile River, with a length of nearly $7000 \mathrm{~km}$, is the largest river in Africa. The total area of Nile basin represents about $10.28 \%$ of the continent's area and spreads over ten countries (Table 1 and Fig. 1). The total area of Nile basin is $3112369 \mathrm{~km}^{2}$, of which the land area suitable for surface irrigation is $920190 \mathrm{~km}^{2}$ and the irrigation potential of Nile basin is $8000 \mathrm{~km}^{2}$. The irrigation potential as percent of the area of the suitable land is $8.69 \%$. This percentage is extremely small as a result of the occurrence of high percentage of lands in the sub-Sahara zone: Sudan and Egypt.

The Nile river flows from south to north over 35 degrees of latitude (FAO, 1995a). It is fed by two main river systems: the White Nile with its sources on the Equatorial lake plateau (Burundi, Rwanda, Tanzania, Kenya, DR Congo and Uganda), and the Blue Nile with its sources in the Ethiopian highlands (FAO, 1995a and Nile Basin Initiative, 2002). These sources are located in humid regions, with an average annual rainfall of $1000 \mathrm{~mm}$. The arid region, of Nile basin, starts from Sudan, which can be divided into three rainfall zones: the extreme south of the country with annual rainfall varying from 1200 to $1500 \mathrm{~mm}$, the fertile clay-plains with annual rainfall from 400 to $800 \mathrm{~mm}$, and the desert zone at northern part where rainfall averages only 20 $\mathrm{mm}$ per year. Further north is Egypt with annual rainfall (precipitation) less than $20 \mathrm{~mm}$ (Table 2).

The area of a specific country within the Nile basin widely varied among countries, and the largest was for Egypt, Ethiopia and Sudan, and the lowest was for Burundi, DR Congo and Rwanda (Tables 3 and 4). There are also wide variations in the irrigation potential among the countries where the highest is belonging to Egypt and Sudan (Tables 3 and 4).

All the waters in Burundi and Rwanda and more than half in Uganda are produced internally, while most of the water resources of Sudan and Egypt originate outside their borders; about $77 \%$ of Sudan's water and 97\% of Egypt's water (FAO, 1995a; McNeely, 1999 and Nile Basin Initiative, 2002).

There are wide variations in the area under irrigation of each country and the largest is that of Sudan and Egypt (Table 4). On the other hand, Burundi and DR Congo agricultural and crop production system are using non-irrigated lands for crop production. However, these two last countries have an arise plans for increasing their cultivated area.

Table 5 shows that the irrigation water requirements, of the country's Nile basin, are the highest for Egypt, Kenya and Sudan countries and the lowest for Burundi, DR Congo, Eritrea and Rwanda. The same trend can be found with respect to the water withdrawn for agriculture from Nile River whether as quantity or as percentage (Nile Basin Initiative, 2002).

\subsection{Food production}

There is a growing concern for food production in Africa and this is especially in the sub-Saharan regions which suffer shortage in the rainfall. Under such conditions, both rainfed and irrigated agriculture should be intensified. While there still exists considerable potential for the future expansion of irrigation, in these regions, the water is growing scarce and, therefore, the need for irrigation is becoming more urgent. In order to enable careful planning for the development of water resources for irrigation, knowledge and data about irrigation potential and rainfed agriculture should be considered clearly. It has been reported that in developing countries, rainfed crop yields (wheat for example) remain far below irrigated crop yields. Rainfed cereal yields averaged 1.5 metric tons per hectare in the developing countries which is half irrigated cereal yields of 3.3 metric tons per hectare in the same countries. This yield is also less than half of the 3.2 metric tons per hectare of rainfed cereal yields, produced on the average, in the developed countries (Rosegrant et al., 2002).

\subsection{Crop Water Needs}

The crop water needs can be supplied from rainfall or from irrigation or by a combination from both. If the rainfall is sufficient to cover the water needs of the crop, irrigation is not required and if there is no rainfall, all water that the crop need has to be supplied by irrigation. It is obvious that part of the rainfall cannot be used by the plant (not effective) and the remaining part is stored in the root zone and can be used by plant (effective rainfall). Factors including; climate, soil texture, soil structure and depth of root zone influence the magnitudes of non-effective and effective rainfall (Brouwer and Heibloem, 1986).

The irrigation water need of a certain crop is the difference between the crop water need and that part of the rainfall which can be used by the crop (the effective rainfall). The crop water needs depend on the climate, the crop type and the growth stage of the crop. The major climatic factors are sunshine, temperature, humidity and wind speed (FAO, 1984 and FAO, 1992a). 
Table 1. The areas and annual rainfall of the river basins in Africa*

\begin{tabular}{lccccc}
\hline \multirow{2}{*}{ River basin } & \multicolumn{2}{c}{ Area } & \multicolumn{2}{c}{ Rainfall (mm/year) } \\
\cline { 2 - 6 } & \multicolumn{1}{c}{$\mathbf{K m}^{\mathbf{2}}$} & \% of Africa & Minimum & Maximum & Mean \\
\hline Senegal & 483,181 & 1.6 & 55 & 2,100 & 550 \\
\hline Niger & $2,273,946$ & 7.51 & 0 & 2,845 & 690 \\
\hline Lake Chad & $2,381,635$ & 7.86 & 0 & 1,590 & 415 \\
\hline Nile & $3,112,369$ & 10.28 & 0 & 2,060 & 615 \\
\hline Rift Valley & 637,593 & 2.1 & 90 & 2,210 & 650 \\
\hline Shebelli-Juba & 810,427 & 2.68 & 205 & 1,795 & 435 \\
\hline Congo/Zaire & $3,789,053$ & 12.51 & 720 & 2,115 & 1,470 \\
\hline Zambezi & $1,351,365$ & 4.46 & 535 & 2,220 & 930 \\
\hline Okavango & 323,192 & 1.07 & 355 & 1,320 & 680 \\
\hline Limpopo & 401,864 & 1.33 & 290 & 1,040 & 530 \\
\hline Orange & 896,368 & 2.96 & 35 & 1,040 & 325 \\
\hline South Interior & 645,826 & 2.13 & 270 & 905 & 435 \\
\hline North Interior (Sahara) & $5,804,463$ & 19.16 & 0 & 700 & 40 \\
\hline Mediterranean Coast & 679,525 & 2.26 & 5 & 895 & 235 \\
\hline North West Coast & 670,621 & 2.21 & 0 & 680 & 145 \\
\hline West Coast & $1,430,196$ & 4.72 & 350 & 3,395 & 1,435 \\
\hline West Central Coast & 704,774 & 2.33 & 775 & 2,830 & 1,785 \\
\hline South West Coast & 516,200 & 1.7 & 10 & 1,600 & 940 \\
\hline South Atlantic Coast & 365,485 & 1.21 & 0 & 555 & 190 \\
\hline Indian Ocean Coast & 663,785 & 2.19 & 125 & 1,770 & 680 \\
\hline East Central Coast & $1,026,252$ & 3.39 & 275 & 2,305 & 960 \\
\hline North East Coast & 725,702 & 2.4 & 0 & 725 & 165 \\
\hline Madagascar & 587,040 & 1.94 & 400 & 3,000 & 1,700 \\
\hline Islands & 9,346 & 0.03 & & & \\
\hline Total for Africa & $30,290,208$ & 100 & & & \\
\hline Hutchinson et al. (1995) and FAO & & & & & \\
\hline (1997) & & & & & \\
\hline
\end{tabular}

Table 2. The annual rainfall $(\mathrm{mm})$ in the countries of Nile basin*

\begin{tabular}{lccc}
\hline & Minimum & Maximum & Mean \\
\hline Burundi & 895 & 1570 & 1110 \\
\hline DR Congo & 875 & 1915 & 1245 \\
\hline Egypt & 0 & 120 & 15 \\
\hline Eritrea & 240 & 665 & 520 \\
\hline Ethiopia & 205 & 2010 & 1125 \\
\hline Kenya & 505 & 1790 & 1260 \\
\hline Rwanda & 840 & 1935 & 500 \\
\hline Sudan & 0 & 1610 & 1015 \\
\hline Tanzania & 625 & 1630 & 1140 \\
\hline Uganda & 395 & 2060 & 615 \\
\hline For Nile basin & 0 & 2060 &
\end{tabular}


Table 3. The country area of Nile basin*

\begin{tabular}{lcccc}
\hline \multirow{2}{*}{ Country } & $\begin{array}{c}\text { Country } \\
\text { area }\left(\mathbf{K m}^{\mathbf{2}}\right)\end{array}$ & $\left(\mathbf{K m}^{\mathbf{2}}\right)$ & $\begin{array}{c}\text { As \% of the total area of } \\
\text { the Nile basin }\end{array}$ & $\begin{array}{c}\text { As \% of the } \\
\text { country in the Nile basin }\end{array}$ \\
\cline { 3 - 4 } & $\mathbf{2 7 , 8 3 4}$ & $\mathbf{1 3 , 2 6 0}$ & $\mathbf{0 . 4 3}$ & $\mathbf{4 7 . 6 4}$ \\
\hline Burundi & $2,344,860$ & 22,143 & 0.71 & 0.94 \\
\hline DR Congo & $1,001,450$ & 326,751 & 10.50 & 32.63 \\
\hline Egypt & 121,890 & 24,921 & 0.80 & 20.45 \\
\hline Eritrea & $1,100,010$ & 365,117 & 11.73 & 33.19 \\
\hline Ethiopia & 580,370 & 46,229 & 1.49 & 7.97 \\
\hline Kenya & 26,340 & 19,876 & 0.64 & 75.46 \\
\hline Rwanda & $2,505,810$ & $1,978,506$ & 63.57 & 8.96 \\
\hline Sudan & 945,090 & 84,200 & 2.71 & 98.09 \\
\hline Tanzania & 235,880 & 231,366 & 7.43 & \\
\hline Uganda & & $3,112,369$ & 100.00 & \\
\hline For Nile basin & & & \\
\hline * FAO $(1997)$ & & &
\end{tabular}

Table 4. Area under irrigation by country of Nile basin and as percentage of country basin and the irrigation potential of each country in the basin*

\begin{tabular}{lcccc}
\hline & \multicolumn{3}{c}{ Area under irrigation } & Irrigation potential \\
\cline { 2 - 5 } & $\left(\mathbf{K m}^{\mathbf{2}}\right)$ & $\begin{array}{c}\text { As \% of the country } \\
\text { basin }\end{array}$ & $\begin{array}{c}\text { As \% of the total area of the } \\
\text { country }\end{array}$ & $\begin{array}{c}\text { I } \\
\text { ( })\end{array}$ \\
\hline Burundi & 0 & 0.00 & 0.00 & 800 \\
\hline DR Congo & 0 & 0.00 & 0.00 & 100 \\
\hline Egypt & 30,780 & 9.42 & 3.07 & 1,200 \\
\hline Eritrea & 151.24 & 0.61 & 0.12 & 22,200 \\
\hline Ethiopia & 231.6 & 0.06 & 0.02 & 1,800 \\
\hline Kenya & 60 & 0.13 & 0.01 & 1,500 \\
\hline Rwanda & 20 & 0.10 & 0.08 & 27,500 \\
\hline Sudan & 19,352 & 0.98 & 0.77 & 300 \\
\hline Tanzania & 100 & 0.12 & 0.01 & 2,020 \\
\hline Uganda & 91.2 & 0.04 & 0.04 & \\
\hline
\end{tabular}

* Nile Basin Initiative (2002)

Table 5. Irrigation water use per country of Nile basin in the year 2000*

\begin{tabular}{|c|c|c|c|c|c|}
\hline Country & $\begin{array}{l}\text { Total renewable } \\
\text { water resources } \\
\qquad\left(\mathrm{Km}^{3}\right)\end{array}$ & $\begin{array}{c}\text { Irrigation } \\
\text { water } \\
\text { requirements } \\
\left(\mathrm{Km}^{3}\right)\end{array}$ & $\begin{array}{l}\text { Water } \\
\text { requirement } \\
(\text { rate in \%) }\end{array}$ & $\begin{array}{c}\text { Water } \\
\text { withdrawal for } \\
\text { agriculture } \\
\left(\mathrm{Km}^{3}\right)\end{array}$ & $\begin{array}{c}\text { Water withdrawal } \\
\text { (as a } \% \text { of } \\
\text { renewable water } \\
\text { resources) }\end{array}$ \\
\hline Burundi & 3.6 & 0.06 & $30 \%$ & 0.19 & $5 \%$ \\
\hline DR Congo & 1283 & 0.03 & $30 \%$ & 0.11 & $0 \%$ \\
\hline Egypt & 58.3 & 28.43 & $53 \%$ & 53.85 & $92 \%$ \\
\hline Eritrea & 6.3 & 0.09 & $32 \%$ & 0.29 & $5 \%$ \\
\hline Ethiopia & 110 & 0.56 & $22 \%$ & 2.47 & $2 \%$ \\
\hline Kenya & 30.2 & 0.3 & $30 \%$ & 1.01 & $3 \%$ \\
\hline Rwanda & 5.2 & 0.01 & $30 \%$ & 0.03 & $1 \%$ \\
\hline Sudan & 64.5 & 14.43 & $40 \%$ & 36.07 & $56 \%$ \\
\hline Tanzania & 91 & 0.56 & $30 \%$ & 1.85 & $2 \%$ \\
\hline Uganda & 66 & 0.03 & $30 \%$ & 0.12 & $0 \%$ \\
\hline
\end{tabular}

\footnotetext{
* Nile Basin Initiative (2002)
} 


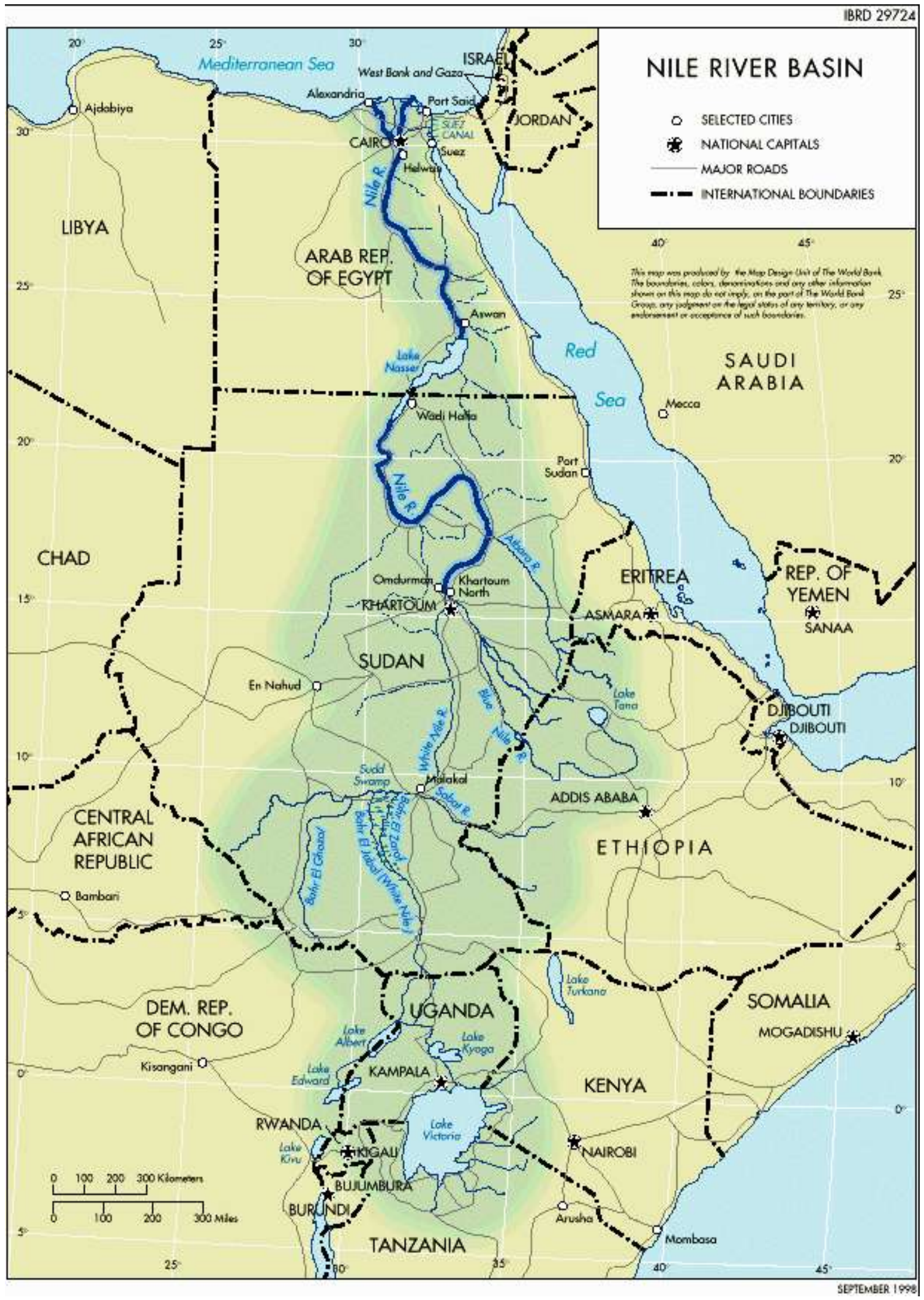

Fig. 1. The countries of Nile River basin 


\section{METHODS}

\subsection{Irrigation potential}

In humid climate, where rainfall is more than 1200 $\mathrm{mm} /$ year, this amount is sufficient to cover the water needs of the various crops. In sub-humid and semi-arid climates, the rainfall range is between 400 and 1200 $\mathrm{mm} / \mathrm{year}$ and this amount are important but not sufficient to cover the water needs of most crops. The crop production in dry season is only possible with irrigation, while the crop production in the rainy season may be possible but unreliable and yield will be less than optimal. In semi-arid and desert climate, the rainfall is less than $400 \mathrm{~mm} /$ year and reliable crop production based on rainfall is not possible and irrigation is thus required. This indicates that there are two factors which determine the amount of irrigation water: the total water needs of the crop and the amount of rainfall which is available.

The assessment of irrigation potential, based on soil and water resources can be carried out by assessing irrigation water requirement (IWR) and net irrigation water requirement (NIWR). Both depend upon cropping pattern and climatic conditions. The climate data can be obtained from the FAOCLIM cd-room (FAO, 1995b). These data set includes long term average of rainfall and reference potential evapotranspiration $\left(\mathrm{ET}_{\mathrm{o}}\right)$ which is calculated by the Penman-Monteith method (FAO, 1992a). Moreover, the FAO's CROPWAT software can be used to compute the NIWR (FAO, 1992b).

The theoretic "Blaney-Criddle" method can be used to calculate the reference evapotranspiration $\left(\mathrm{ET}_{\mathrm{o}}\right)$. This method is simple, using measured data on temperature and latitude (Table 6). However, the method is not very accurate. It provides a rough estimates or "order of magnitude" only as compared to Penman method which is rather complicated (FAO, 1984).

The "Blaney-Criddle" method always refers to the "mean monthly values", both for the temperature and the $\mathrm{ET}_{0}$ The used formula is:

$\mathrm{ET}_{\mathrm{o}}=\mathrm{p}\left(0.46 \mathrm{~T}_{\text {mean }}+8\right)$

Where:

$\mathrm{ET}_{\mathrm{o}}$ : reference crop evapotranspiration ( $\mathrm{mm} /$ day) as an average for a period of one month.

$\mathrm{T}_{\text {mean }}$ : mean daily temperature $\left({ }^{\circ} \mathrm{C}\right)$.

P: mean daily percentage of annual daytime hours.

To determine the values of "P" and mean temperature, the approximate latitude and mean temperature of the area are estimated (FAO, 1984; and Brouwer and Heibloem, 1986). The mean values of these two parameters are shown in Tables 6 and 7.

The crop water need (crop evapotranspiration: $\mathrm{ET}_{\text {crop }}$ ) is obtained by the formula:

$\mathrm{ET}_{\text {crop }}=\mathrm{ET}_{\mathrm{o}} \times \mathrm{Kc}$

Where $\mathrm{Kc}$ is the crop factor (FAO, 1984).

Usually, $\mathrm{ET}_{\mathrm{o}}$ and $\mathrm{ET}_{\text {crop }}$ are expressed in the same unit: $\mathrm{mm} /$ day (as an average for a period of one month) or in $\mathrm{mm} /$ month.

The crop factor $(\mathrm{Kc})$ depends on both the type of the crop, growth stage of this crop and the climate.

The "Blaney-Criddle" method divides the growing period of a crop into four growth stages: initial, development, mid-season and late-season. The sum of these four growth stages is the "total growth period: TGP" in days. Also, for each crop, there are four Kc values which have to be determined (FAO, 1984).

Table 6. Estimated mean values of temperature and latitude of the countries of Nile basin*

\begin{tabular}{lccccc}
\hline \multirow{2}{*}{ Country } & \multicolumn{3}{c}{ Temperature $\left.{ }^{\circ} \mathbf{C}\right)$} & \multicolumn{2}{c}{ Latitude } \\
\cline { 2 - 6 } & Min. & Max. & Mean & Range & Mean \\
\hline Burundi & 17 & 23 & 20 & $03^{0} 00^{`} \mathrm{~S}-02^{0} 00^{`} \mathrm{~S}$ & $02^{0} 30^{`} \mathrm{~S}$ \\
\hline DR Congo & 10 & 30 & 20 & $14^{0} 00^{`} \mathrm{~S}-06^{0} 00^{`} \mathrm{~N}$ & $08^{0} 00^{`} \mathrm{~N}$ \\
\hline Egypt & 11 & 40 & 28 & $21^{0} 00^{`} \mathrm{~N}-31^{0} 00^{`} \mathrm{~N}$ & $26^{0} 00^{`} \mathrm{~N}$ \\
\hline Eritrea & 18 & 32 & 25 & $12^{0} 00^{`} \mathrm{~N}-18^{0} 00^{`} \mathrm{~N}$ & $15^{0} 00^{`} \mathrm{~N}$ \\
\hline Ethiopia & 8 & 25 & 16.5 & $03^{0} 00^{`} \mathrm{~N}-15^{0} 06^{`} \mathrm{~N}$ & $10^{0} 00^{`} \mathrm{~N}$ \\
\hline Kenya & 12 & 28 & 20 & $05^{0} 00^{`} \mathrm{~S}-05^{0} 00^{`} \mathrm{~N}$ & $00^{0} 00^{`}$ \\
\hline Rwanda & 23 & 28 & 25.5 & $02^{0} 30^{`} \mathrm{~S}-02^{0} 00^{`} \mathrm{~S}$ & $02^{0} 15^{`} \mathrm{~S}$ \\
\hline Sudan & 17 & 43 & 29.5 & $11^{0} 00^{`} \mathrm{~N}-21^{0} 00^{`} \mathrm{~N}$ & $16^{0} 00^{`} \mathrm{~N}$ \\
\hline S. Sudan & 22 & 30 & 26.5 & $03^{0} 00^{`} \mathrm{~N}-13^{0} 00^{`} \mathrm{~N}$ & $08^{0} 15^{`} \mathrm{~N}$ \\
\hline Tanzania & 15 & 28 & 21.5 & $11^{0} 50^{`} \mathrm{~S}-01^{0} 00^{`} \mathrm{~S}$ & $06^{0} 30^{`} \mathrm{~S}$ \\
\hline Uganda & 8 & 32 & 20 & $02^{0} 00^{`} \mathrm{~S}-04^{0} 00^{`} \mathrm{~N}$ & $03^{0} 00^{`} \mathrm{~N}$ \\
\hline
\end{tabular}

* Brouwer and Heibloem (1986) 
Table 7. The value of the mean daily percentage $(P) *$

\begin{tabular}{|c|c|}
\hline Country & $\mathbf{P}$ \\
\hline Burundi & 0.270 \\
\hline DR Congo & 0.280 \\
\hline Egypt & 0.300 \\
\hline Eritrea & 0.275 \\
\hline Ethiopia & 0.280 \\
\hline Kenya & 0.270 \\
\hline Rwanda & 0.270 \\
\hline Sudan & 0.280 \\
\hline S. Sudan & 0.280 \\
\hline Tanzania & 0.285 \\
\hline Uganda & 0.270 \\
\hline
\end{tabular}

* Brouwer and Heibloem (1986)

The water required by the plant can be supplied in various ways: by rainfall, by irrigation, or by a combination of both. In the case where all the water needed by the plant is provided by rainfall, irrigation is not required and the irrigation water need (IWN) equals zero (IWN $=0$ ). In the case where there is no rainfall, the water has to be supplied by irrigation and hence, the IWN equals the $\mathrm{ET}_{\text {crop. }}$ In some cases, however, part of the $\mathrm{ET}_{\text {crop }}$ is supplied by rainfall and the remaining part by irrigation. In this case, the following formula is applied:

IWN $=\mathrm{ET}_{\text {crop }}-\mathrm{P}_{\mathrm{e}}$

Where $P_{e}$ is the effective rainfall (effective precipitation) in $\mathrm{mm} / \mathrm{month}$. The $\mathrm{P}_{\mathrm{e}}$ value is obtained by the formula:

$\mathrm{P}_{\mathrm{e}}=0.8 \mathrm{P}-25$ if $\mathrm{P}>75 \mathrm{~mm} / \mathrm{month}$

$\mathrm{P}_{\mathrm{e}}=0.6 \mathrm{P}-10$ if $\mathrm{P}<75 \mathrm{~mm} / \mathrm{month}$

Where $\mathrm{P}$ is the precipitation or rainfall in $\mathrm{mm} /$ month.

\section{RESULTS AND DISCUSSION}

\subsection{Irrigation Water Need for Sorghum}

In the present investigation, sorghum (Sorghum bicolor) is used because it is a common cultivated crop in the countries of Nile basin for grains production and/or for fodder. It is relatively tolerant to salinity and is cultivated at wide range of geographical areas. This study represents "comparative data" about IWN of this crop when cultivated in the countries of Nile basin.

According to "Blanery and Criddle" method, there are five steps required for calculating the IWN of sorghum; the determination of $\mathrm{ET}_{\mathrm{o}}, \mathrm{Kc}, \mathrm{ET}_{\text {crop }}$, effective rainfall and then IWN. The mean values of $\mathrm{ET}_{\mathrm{o}}$ and $\mathrm{ET}_{\text {crop }}$ are given in Table 8.

The values of $\mathrm{Kc}$ for sorghum at the initial growth stage, at development stage, mid-season stage and late stage are $0.35,0.75,1.15$ and 0.65 , respectively (FAO, 1984). The approximate duration of the four growth stage is $20,30,40$ and 30 days, respectively with total growth period (TGP) of 120 days.

Table 9 showed wide variations in the values of $\mathrm{ET}_{\text {crop }}(\mathrm{mm} / \mathrm{TGP})$ as a result of geographical and consequently climatic conditions. The highest values are those of sorghum cultivated in Egypt, Sudan and Eritrea. At certain conditions, the water demand of the crop is potentially increasing according to climatic conditions but the water supply from the rainfall may decline or may not full satisfy the demand. According to Table 9, it is clear that IWN of sorghum, cultivated in the countries of Nile basin, is influence by climatic conditions. The highest IWN is concerned with countries of the desert climate (Sudan and Egypt) and the lowest is concerned with countries of humid climate (DR Congo, Ethiopia, Uganda and S. Sudan). The water save percentage, as a result of rainfall, is the highest in humid countries such as DR Congo, Ethiopia and Uganda (Table 9) while that of Egypt or Sudan was nil because of the very low or absent rainfall. This reveals that crop production in Sudan and Egypt, based on rainfall, is not possible and irrigation is very essential.

\subsection{Irrigation Water Needs for Maize and Cotton}

Maize (Zea mays) and cotton (Gossypian hirsutum) are two main crops commonly cultivated in the countries of Nile basin. While maize is moderately sensitive to salinity, cotton is tolerant to salinity. Both are considered of high importance because they contribute economically for the benefits of the farmers and countries in general. Both have high irrigation water demands because both are summer field crops. Tables 10 and 11 represent data about the variations in crop evapotranspiration $\left(\mathrm{ET}_{\text {crop }}\right)$ and irrigation water needs (IWN). It is clear that the IWN for maize is lower than that of cotton. It is also clear that rainfall contributes, with different percentages, in water supply to plants. 
Table 8. Mean values of ETo and ETcrop ( $\mathrm{mm} / \mathrm{day})$ at the four growth stages of sorghum grown in countries of Nile basin*

\begin{tabular}{lcccccccc}
\hline \multirow{2}{*}{ Country } & \multicolumn{9}{c}{ ET $_{\mathbf{0}}$} & $\mathbf{3}$ & \multicolumn{3}{c}{ ET $_{\text {crop }}$} \\
\cline { 2 - 9 } & $\mathbf{1}$ & $\mathbf{2}$ & $\mathbf{3}$ & $\mathbf{4}$ & $\mathbf{1}$ & $\mathbf{2}$ & $\mathbf{3}$ & $\mathbf{4}$ \\
\hline Burundi & 4.64 & 4.64 & 5.36 & 5.36 & 1.62 & 3.48 & 5.90 & 3.48 \\
\hline DR Congo & 4.82 & 4.82 & 4.64 & 4.64 & 1.69 & 3.62 & 5.10 & 3.02 \\
\hline Egypt & 5.64 & 6.06 & 6.27 & 6.69 & 1.97 & 4.55 & 6.90 & 4.35 \\
\hline Eritrea & 5.27 & 5.46 & 5.66 & 5.66 & 1.84 & 4.10 & 6.23 & 3.68 \\
\hline Ethiopia & 4.82 & 4.82 & 4.99 & 4.99 & 1.68 & 3.62 & 5.99 & 3.24 \\
\hline Kenya & 4.64 & 4.64 & 4.64 & 4.64 & 1.62 & 3.48 & 5.10 & 3.02 \\
\hline Rwanda & 4.64 & 4.64 & 5.36 & 5.36 & 1.62 & 3.48 & 5.90 & 3.48 \\
\hline Sudan & 5.33 & 5.52 & 5.70 & 5.72 & 1.87 & 4.14 & 6.27 & 3.72 \\
\hline S. Sudan & 4.89 & 5.10 & 5.21 & 5.21 & 1.71 & 3.83 & 5.73 & 3.39 \\
\hline Tanzania & 4.64 & 4.64 & 5.20 & 5.20 & 1.62 & 3.48 & 5.72 & 3.83 \\
\hline Uganda & 4.64 & 4.64 & 5.10 & 5.10 & 1.62 & 3.48 & 5.61 & 3.32 \\
\hline
\end{tabular}

*FAO (1997)

Table 9. Mean values of $\mathbf{E T}_{\text {crop }}$, IWN of sorghum and water saved in each country

\begin{tabular}{|c|c|c|c|c|}
\hline \multirow{2}{*}{ Country } & \multirow{2}{*}{$\mathbf{E T}_{\text {crop }}(\mathbf{m m} / \mathbf{T G P})$} & \multirow{2}{*}{ IWN (mm/TGP) } & \multicolumn{2}{|c|}{ Water saved } \\
\hline & & & $\mathrm{mm} / \mathrm{TGP}$ & \% of ET $\mathrm{ET}_{\text {crop }}$ \\
\hline Burundi & 477 & 277 & 200 & 41.9 \\
\hline DR Congo & 450 & 230 & 220 & 48.9 \\
\hline Egypt & 582 & 582 & 0 & 00.0 \\
\hline Eritrea & 519 & 463 & 53 & 10.2 \\
\hline Ethiopia & 459 & 239 & 220 & 47.9 \\
\hline Kenya & 430 & 350 & 80 & 18.6 \\
\hline Rwanda & 477 & 337 & 140 & 29.4 \\
\hline Sudan & 524 & 524 & 0 & 00.0 \\
\hline S. Sudan & 480 & 180 & 300 & 62.5 \\
\hline Tanzania & 475 & 287 & 188 & 39.6 \\
\hline Uganda & 460 & 240 & 220 & 47.8 \\
\hline
\end{tabular}

Values of the quantity of water saved, as a result of rainfall contribution in water needs of plants, varied among countries, and were the highest with respect to Burundi, DR Congo, Ethiopia, Kenya, Rwanda, Tanzania, Uganda and S. Sudan for both maize and cotton plants. On the other hand, Egypt and Sudan are considered countries suffering severe rainfall water shortage and $100 \%$ of the IWN must supplied be from irrigation. Thus, the water saved as a result of satisfactory amounts of rainfall can contribute positively towards water supply to both Egypt and Sudan.

\section{CONCLUSION}

The rainfall in the Nile River basin is the highest in the humid region (mean value of $1000 \mathrm{~mm} / \mathrm{year}$ ) and the lowest in the semi-arid and desert region (mean value of $20 \mathrm{~mm} /$ year or less). As a result, the irrigation potential varies markedly among the countries of the Nile basin. The water withdrawals as percentage of renewable water are 5.0 for Burundi, 0.0 for DR Congo, 92.0 for Egypt, 5.0 for Eritrea, 2.0 for Ethiopia, 3.0 for Kenya, 1.0 for Rwanda, 56.0 for Sudan and 1.0 for Uganda. According to the quantities of annual renewable water sources; water management in the countries of Nile basin is considered very poor and therefore proper strategy for renewable water and irrigation water management are required for attaining an expansion in the cultivated lands for fodder and food production.

Irrigation water need (IWN) based on the data obtained (ETo, ETcrop, and Pe) by using the "Blaney Criddible" method improved the occurrence of wide variations in IWN by sorghum plant cultivated in the countries of Nile basin. The mean values of IWN are the highest for Egypt and Sudan (582 and $524 \mathrm{~mm} / \mathrm{TGP}$, respectively). Because of the high rainfall (in the humid region), the water expected to be saved from irrigation as percentage of ET crop are 48.9, 47.9 and 47.8 for DR Congo, Ethiopia and Uganda, respectively. Similar data are presented for maize and cotton in these countries. It can be suggested, therefore, that a plenty of renewable water, reaching the cultivated lands from rainfall, in the humid region of the continent, can be saved for irrigation of the cultivated lands of the semi-arid and desert regions in Egypt and Sudan. 
Table 10. Mean values of $E T_{\text {crop }}$, IWN of maize and water saved in each country

\begin{tabular}{lcccc}
\hline \multirow{2}{*}{ Country } & \multirow{2}{*}{ ET $_{\text {crop }}(\mathbf{m m} / \mathbf{T G P})$} & \multirow{2}{*}{$\mathbf{I W N}(\mathbf{m m} / \mathbf{T G P})$} & \multicolumn{2}{c}{ Water saved } \\
\cline { 3 - 5 } & 589 & 339 & $\mathbf{\text { mm}} / \mathbf{T G P}$ & \% of ET $_{\text {crop }}$ \\
\hline Burundi & 612 & 362 & 250 & 42.4 \\
\hline DR Congo & 716 & 716 & 0 & 40.9 \\
\hline Egypt & 648 & 563 & 85 & 00.0 \\
\hline Eritrea & 589 & 339 & 250 & 13.1 \\
\hline Ethiopia & 589 & 214 & 275 & 42.4 \\
\hline Kenya & 589 & 249 & 250 & 46.7 \\
\hline Rwanda & 677 & 677 & 0 & 42.4 \\
\hline Sudan & 589 & 289 & 300 & 00.0 \\
\hline S. Sudan & 589 & 289 & 300 & 50.9 \\
\hline Tanzania & 589 & 289 & 300 & 50.9 \\
\hline Uganda & & & 50.9 \\
\hline
\end{tabular}

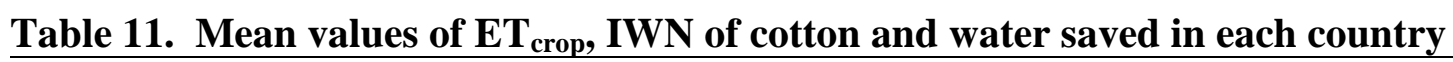

\begin{tabular}{lcccc}
\hline \multirow{2}{*}{ Country } & \multirow{2}{*}{ ET $_{\text {crop }}(\mathbf{m m} / \mathbf{T G P})$} & \multirow{2}{*}{$\mathbf{I W N}(\mathbf{m m} / \mathbf{T G P})$} & \multicolumn{2}{c}{ Water saved } \\
\cline { 3 - 5 } & & & $\mathbf{\text { mm}} / \mathbf{T G P}$ & \% of $\mathbf{E}_{\text {crop }}$ \\
\hline Burundi & 684 & 384 & 300 & 43.8 \\
\hline DR Congo & 711 & 411 & 300 & 42.2 \\
\hline Egypt & 868 & 868 & 00 & 00.0 \\
\hline Eritrea & 749 & 644 & 100 & 13.4 \\
\hline Ethiopia & 644 & 344 & 300 & 46.6 \\
\hline Kenya & 684 & 374 & 330 & 48.3 \\
\hline Rwanda & 684 & 684 & 300 & 43.9 \\
\hline Sudan & 832 & 532 & 00 & 00.0 \\
\hline S. Sudan & 644 & 344 & 300 & 46.6 \\
\hline Tanzania & 684 & 384 & 300 & 43.9 \\
\hline Uganda & 644 & 344 & 300 & 46.6 \\
\hline
\end{tabular}

\section{REFERENCES}

Alcamo, J., Henrichs, T., and Rosch, T. (2000) World water in 2025; Global modeling and scenario analysis for the world commission on water for the $21^{\text {st }}$ century. Kassel World Water Series Report No. 2, Kassel, Germany, Center for Environmental System Research, University of Kassel.

Brouwer, C. and Heibloem, M. (1986) Irrigation water management: Irrigation water needs. Training manual No. 3. Land and Water Development Division, FAO, Rome.

Crisman, T.L., Chapman, L.J., Chapman, C.A., and Kaufman, L.S. (2003) Conservation, Ecology, and Management of African Fresh Waters. Univ. Press of Florida. Gainesville, FL. USA.

FAO (1984) Guidelines for predicting crop water requirements. FAO Irrigation and Drainage Paper 24, FAO, Rome.

FAO (1992a) Crop water requirement. FAO Irrigation and Drainage Paper 24, FAO, Rome.

FAO (1992b) CROPWAT: A computer program for irrigation planning and management. FAO Irrigation and Drainage Paper 46, FAO, Rome.
FAO (1995a) Irrigation in Africa in Figures. FAO, Rome.

FAO (1995b) FAOCLIM cd-rome. Agroclimatic database. Rainfall and evaporation figures. FAO, Rome.

FAO (1997) Irrigation Potential in Africa: A basin approach. FAO Land and Water Bulletin 4. FAO, Rome.

FAO (2000) FAOSTAT database. Http://faostat.fao.org.

Hutchinson, M.F., Nix, H.A., McMahon, J.P., and Ord, K.D. (1995) The development of a topographic and climate data base for Africa. Australian National University.

McNeeley, J.A. (1999) Freshwater management: From conflict to cooperation. World Conservation IUCN Bulletin, Issue 2. International Union for Conservation of Nature and Natural Resources. Gland, Switzerland: World Conservation Unit. http://www.iucn.org/bookstore/bulletin/1999/wc2/content/co nflict.pdf.

Nile Basin Initiative (2002) Introduction to the Nile River Basin, Uganda: The Nile Basin Initiative Secretariat. http://www.nilebasin.org/IntroNR.htm.

Rosegrant, M.W., Cal, X., and Cline, S. A. (2002) World Water and Food to 2025: Dealing with Scarcity. International Food Policy Research Institute, Washington, D.C. USA. 


\section{الملخص العربي}

\section{استراتيجية الاحتياجات المائية لنباتات رئيسية تزرع فى دول حوض فر النيل}

$$
\text { إبراهيم حسين السكرى، علاء فاروق أبو كيلة }
$$

الفرق بين الاحتياجات المائية للنبات (البخر نتح للمحصول) والكمية

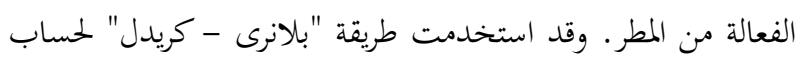
البخر نتج المرجعى ومعامل المصصول في حساب كمية حاجة النبات من ماء الرى وقد أتخذ نبات الذرة الرفيعة كمثال. وتوضح الفئ النتائج

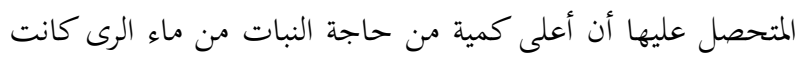
خاصة بمصر والسودان (582، 524 مم/طول فترة النمو على التوالى) وأقل كمية كانت خاصة بالكونغو الديموقراطية، إثيوبيا، أوغندا وجنوب السودان(230، 239، 240، 180 مم/طول فترة النمو على التوالى). قدرت كمية مياه النيل الممكن ادخارها وتوفيرها من مياه الرى

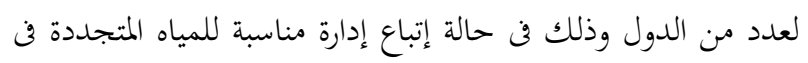

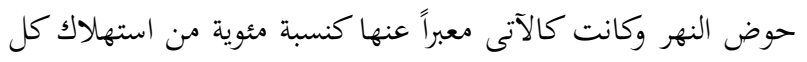
دولة من الماء: 41.9 فن بورندى، 48.9 في الكونغو الديموقراطية، 47.8 في أوغندا، 62.5 في جنوب السودان على التوالى. هذه النسبة من الماء يمكن إضافتها إلى ما يخص دول فقيرة فن مصادر الماء العذب جنب المتجدد كما في حالة مصر والسودان.
تتدفق مياه حوض فر النيل من الجنوب إلى الشمال عبر 35 درجة لخطوط العرض والذى يمتد من المنطقة الرطبة إلى المنطقة الصحراوية. وتقع دول بورندى، الكونغو الديموقراطية، مصر، ارتريا،

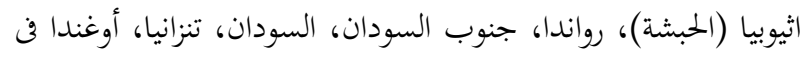

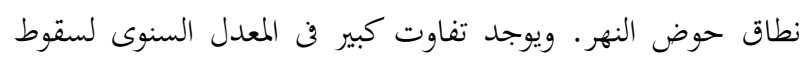

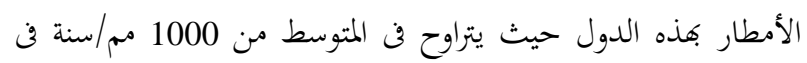
دول المناطق الرطبة (بورندى والكونغو الديموقراطية) إلى أقل من 20 مم/سنة في دول المناطق النصف صحراوية والصحراوية (السودان ومصر). وتبلغ كمية المياه المستخدمة من ماء النيل في الرى معبراً عنها كنسبة مئوية في دول حوض أهار كالآتى: 0.5 بورندى، 0.0 الكونغو 0.0

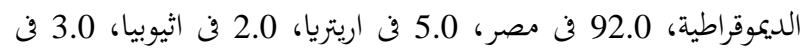

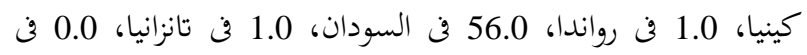

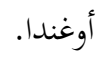

يحصل النبات على احتياجاته المائية إما من الأمطار أو الرى أو

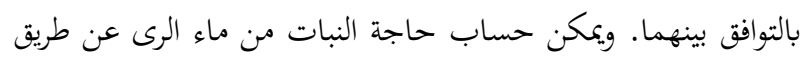

